\section{Drawing on many traditions: an ecumenical kenotic christology}

\author{
Thomas Senor
}

\section{INTRODUCTION}

The traditional Christian doctrine of the incarnation is profound and yet deeply confounding. On the one hand, it stirs the heart and has great spiritual and emotional value. The claim that the Creator-God, the omnipotent source of all that is, cares enough about humanity to take on our nature and endure the brutality that characterizes the Passion of Christ is profoundly moving. Furthermore, it allows the Christian to have confidence that God not only has propositional knowledge of what we experience and of our difficulties and hardships, but that God is able to empathize with us too. In short, the doctrine of the incarnation brings God to us and puts God in our shoes in a way that no non-incarnational theology ever could. Yet while the doctrine of the God-man certainly stirs the soul, it just as surely confounds the mind, and in many ways and along a host of different dimensions. For example, in claiming that Jesus Christ is both 'fully God' and 'fully human' the Christian is claiming that God the Son has (or at least had) a pair of natures. Yet one might have thought a nature is that which makes one what one is. If that is right, how is it possible for a single individual to have multiple natures? Second, even if it is possible for an individual to have more than one nature, how is it possible for the nature of God and the nature of humanity to be exemplified in a single individual? Even if some natures are somehow compossible, why should we think that the infinite divine nature would be compatible in a single individual with the puny, metaphysically wispy nature of humanity? Ideally, these and other similar questions should be answered by a good account of the metaphysics of the incarnation.
In developing a philosophically satisfying christology, one will have to make a decision at the very beginning: is consistency with the ecumenical creeds and the decrees of the early councils a condition of adequacy on one's account of the incarnation? If so, there are very clear constraints on what one's christology will look like. If not, what kinds of constraints will be acknowledged? Now one might be tempted to think that either you develop your theory of the incarnation within the constraints of the tradition or anything goes. I don't think that is right, however. For instance, one might hold that consistency with scripture is all that matters. If, given the right interpretation of scripture in light of the contemporary biblical scholarship, one constructs an account of the nature of Christ that best explains the scriptural data but that doesn't comport particularly well with, say, the Nicene Creed, one will certainly have been operating under serious constraints, even if they are not as onerous as they are on one who accepts the creeds and councils. It's actually an interesting question, it seems to me, what one should do if one sincerely believed that the scriptural and, for want of a better term 'traditional' view of the nature of Christ were to diverge. Obviously, different branches of the Christian church, if they are to follow their own rules, are going to be committed to different conclusions. Be all of that as it may, I intend to sketch an incarnational view with the goal of conforming to both scripture and the creeds and councils.

So conformity with the tradition is a constraint on our philosophical theorizing about the incarnation. But stated that way, we don't get much help. For we need to know what that commits us to if we are to know our boundaries. So here is a list of what I think are desiderata of a successful metaphysics of the incarnation, traditionally construed:

1. It must entail that Jesus Christ and God the Son are identical.

2. It must entail that God the Son has whatever properties are essential for divinity even during his earthly ministry.

3. It must entail that Jesus Christ has all the properties that are essential for humanity.

4. It must not emaciate either the divinity or the humanity of God incarnate.

5. While providing an account that helps resolve logical difficulties in the doctrine, it must not remove all of the mystery from the incarnation.

While points (1)-(3) are straightforward, the fourth and fifth points could use a little explaining. Let's take them in order. In the first paragraph of this essay, I noted that the doctrine of the incarnation is both intellectually confounding and deeply moving. An attempt to give a theory or model of the metaphysics of God incarnate is primarily aimed at making the doctrine less confounding. But it should not do this at the expense of emptying it of its emotive force because, or so it seems to me, its emotive effect is tightly linked 
to its spiritual and perhaps even soteriological effect. So, for instance, an account which resolved the logical difficulties but which entailed that Jesus Christ never suffered pain or felt abandoned should be rejected for failing to satisfy desideratum (4). Alternatively, a theory that entailed that Jesus' divinity was, to all intents and purposes, ersatz divinity should similarly be rejected. With regard to (5), any account that would try to explain everything of significance in the incarnation in such a way as to completely remove a sense of mystery is surely too simplistic and fails to keep in mind the enormous cognitive and ontological gulf that separates humanity from the divine.

I'm not claiming that the five points above are exhaustive of the desiderata for an account or model of the metaphysics of the incarnation. But, if one wants one's view to be in conformity with the scriptures, creeds, and councils and to be spiritually satisfying, one's account had better play by these rules.

In what follows, I will sketch three approaches to understanding the nature of the incarnation that can be found in the contemporary philosophical theological literature. These are (1) Thomas Morris's two-minds theory, (2) the compositional account one finds in Aquinas and recently expanded and defended independently by Eleonore Stump and Brian Leftow, and (3) the kenotic view as one finds it in the writings of Ronald Feenstra, Stephen Davis, and C. Stephen Evans. After evaluating each position, I will argue that a broadly kenotic christology that incorporates insights from the two-minds view and the compositional account is the best prospect for a metaphysics of the incarnation that satisfies the five desiderata. Because there is so much to be done in this paper, both my presentations of the positions and my objections to them will have to be somewhat brief. Similarly, at the essay's end what I will give will be a sketch of an account. So while I hope that there will be some level of cogency and convincingness to what I argue, I do not pretend to be presenting anything that looks like a knock-down argument against any of these positions or a particularly strong argument for the position I favour.

\section{MORRIS'S TWO-MINDS VIEW}

In his ground-breaking work The Logic of God Incarnate, ${ }^{1}$ Thomas V. Morris defends an account of the incarnation that appears to satisfy our desiderata. There are two main moves that Morris makes: first, he marks the distinction between being 'fully human' and being 'merely human' and claims that there is no reason in principle why a divine person couldn't be fully human even

\footnotetext{
${ }^{1}$ Morris (1986).
}

though that person could not be merely human. Second, Morris argues that establishing that, in principle, human and divine natures are compatible is necessary but insufficient for providing a suitable account of the incarnation. Basically, the reason for this is that such an account might not satisfy our fourth desideratum: Jesus might be technically human but if he experiences the world only as God, then he is not 'like us in all ways except sin'-or for that matter very much like us at all. So in an effort to give us a more typically human Jesus, Morris develops the two-minds view, according to which Jesus Christ had two minds - one human and the other divine. Let's now look al each component a little more carefully.

\section{Natural kinds and 'full' and 'mere' humanity}

The primary problem that drives Morris's account of the incarnation is the objection that the doctrine can't possibly be true since it involves ascribing logically incompatible properties to Jesus Christ. Following Morris, let's call this the 'Incoherence Objection'. The idea is that if Jesus is God, then he must have whatever characteristics are essential to divinity. Such properties include omnipotence, omniscience, omnipresence, etc. But, the objector continues, it is a necessary truth that no human being can have any of those propertics since by definition (or, better, by nature) humans are limited in power, knowledge, and spatial location. So if he is both divine and human, then Jesus has a long string of pairs of incompatible properties (or at least properties and their logical complements).

According to Morris, the first counter-move that the Christian should make is to inquire about the epistemic status of the claims about what is necessary for being human. Why should she think that it is a necessary truth that no human being be, for example, omnipotent? The response is that this just falls out of either the definition of the term 'humanity' or the content of the concept. That is, we might think of humanity as being something like a nominal essence. This will be a collection of properties that we use when we classify objects in ordinary life. Just as the nominal essence of gold will be those properties we commonly associate with gold, so the nominal essence of humanity consists of those properties we typically associate with being human. The point is that nominal essences are known a priori. One reflects on one's concept and what one finds embedded there is an essential part of it. So when we reflect on our concept of humanity, we can see that having various limitations of finitude are crucial components of the concept.

Morris argues that this is the wrong way to think about the nature of humanity. Instead, we should treat it along the lines of a 'real essence' or what 
has come to be called a 'natural kind essence'. Consider the often-used example of tigers. If we stick with cluster concepts or nominal essences we define them as large, striped, carnivorous quadrupeds that are typically black and yellow. While some such list of properties is generally fine for picking out tigers when one goes to the zoo, it clearly does not get at the essence of tigerhood. For a tiger can lose one or more of its legs, its taste for meat, and even its stripes without ceasing to be a tiger. To be a tiger is to be a member of a certain zoological type and such types are individuated the genetic level. So even though in ordinary life we use certain epistemically available markers to pick out something as a tiger, such markers do not get at the essence of the natural kind. There are, of course, some kinds (speaking a bit more loosely here) that are a priori known. For example, to be a bachelor is to be a member of a (non-natural) kind and the method for finding out what is necessary and sufficient for bachelorhood is a priori reflection on the concept. Concepts that are a priori knowable along these lines are known as 'cluster concepts'. They just consist in clusters of other concepts that compose them.

Once we've distinguished between natural kind concepts and cluster concepts, the relevant question is into which classification does humanity fall? The answer should be apparent: the concept of 'human being' is a lot more like that of 'tiger' than that of 'bachelor'. So we should figure that what it is to be human is to be a certain zoological type (perhaps with an additional, immaterial part; I don't mean to be begging questions against dualism). But if humanity is a natural kind, then a determination of its essence is not to be done via conceptual analysis or a priori reflection of any kind, but by a posteriori investigation (and perhaps metaphysical theory development). In short, there is no good reason to think that 'not being omnipotent' will just fall out of 'is human' because almost nothing just falls out of a natural kind concept. Once this point is made, we can see that there is significant flexibility in what the Christian might say about the nature of humanity and there is in principle no reason why she can't deny that a human must be contingent, limited in knowledge and power, etc.

Morris next introduces his distinction between mere and full humanity. To be merely human is to be fully human and also not a member of a higher ontological type; to be fully human is simply to have all of the qualities necessary for humanity. The Christian, then, can say that there is no a priori or even a posteriori reason for thinking that nothing that is human could possess any of the omni-properties. Of course, if God the Son is identical to Jesus Christ, then Jesus can't be said to be merely human, but that doesn't rule out his full humanity. So the first part of Morris's response to the incoherence objection is to deny that being human requires lacking the omni-properties on the ground that kind essences aren't known via a priori reflection.

\section{Two minds}

As mentioned earlier, Morris has foreseen a potentially crippling objection to his account.

But this appears to leave us with a person who was Jesus of Nazareth and was omniscient, omnipotent, omnipresent, and necessarily existent. Of course, we ordinary human beings exemplify the logical complements of each of these attributes of deity... Such properties as being restricted in knowledge, limited in power, localized in presence, and contingent in existence will be held to be at most essential for being merely human. But this can appear to be a near reductio for the strategy. Can a fully human being be ommipotent, omniscient, and the rest? Did Jesus have these properties? The New Testament portrays him as at times tired, hungry, and as lacking knowledge of certain things. And surely no amount of modal manipulation of human nature can render it possible that this man was also incorporeal, immutable, and impassible. At this point, the initially promising strategy for blocking the incoherence charge can appear to break down. ${ }^{2}$

Indeed. But Morris has a solution, a way of allowing him to continue to hold the claim that Jesus had all of the essential attributes of God without taking away from his experience as a human being. The answer, according to Morris, is to posit two minds in the incarnate God-one is the omniscient divine mind that is from eternity and is the seat of the omni-properties had by Jesus Christ. The other mind is the earthly mind which came into existence around $3 \mathrm{BCE}$ and grew in knowledge and wisdom in much the same way that the average human person's mind developed in first-century Palestine. The twominds view is supposed to help with the objection in the above quotation because it was the human mind that was primarily operative in the earthly life of Jesus. Morris postulates that there was an asymmetrical accessing relationship between the minds: the divine mind had complete access to the thoughts, experiences, beliefs, etc., of the human mind but the human mind had limited access to the divine mind. In fact, the human mind could only know of the divine mind what the divine mind revealed to it. So the mind that was conscious in the earthly life of God incarnate was the finite mind that was taken on with the human nature. For the most part, then, the experience of Christ was like the experience of those around him. How much the human mind knew about its relationship with the divine mind is an issue that different two-minds theorists may disagree about, and is to be decided on (as far as possible) in light of the scriptural record.

\footnotetext{
${ }^{2}$ Morris (1986: 72-3).
} 
There is one further refinement that needs mentioning. Morris notes that were he to end his account here he'd have a major problem: for the asymmetrical accessing relation that the earthly mind of Jesus has to the mind of God the Son is also had by each of us with the mind of God the Son. The Sor has complete access to our mental life and we have whatever access to his he allows us to have. So wherein is the uniqueness of Christ? Morris's answer is that unlike us, the causal and cognitive powers of the earthly mind are none other than the cognitive and causal powers of God the Son. But the rest of us have independent cognitive and causal powers. Our mental powers are brought about by God but they are numerically distinct; the powers of Jesus just are the powers of God the Son.

\section{Evaluation of Morris's view}

While this overview is admittedly sketchy, it does provide enough of the motivation and detail of the theory to allow for at least a prima facie evaluation. The first thing to notice is that it seems to do very well regarding the five desiderata. It insists on the identification of God the Son and Jesus Christ and entails that this divine person has all the kind, essential properties of divinity and humanity. The two-minds component of the theory allows a plausible case to be made for claiming that the conscious life of Jesus was very different from the consciousness of God the Son, even though the latter was in some sense in the background. Furthermore, it is clear that a fair bit of mystery remains. In particular, the matter of what it would be like for a single person to have two fully conscious minds is beyond the ability of human beings to enter into empathetically.

For some readers, the mystery that remains is rather too much. For, it has been contended, persons necessarily have single minds. Even if there are periods of mental fracture where streams of consciousness come apart, what unites the minds into a single person is their causal history and, perhaps, their being grounded in the same physical organ. Split personalities can then be regarded as one person in a way that two minds that are not grounded in the same underlying stuff and which can never be integrated with each other cannot. Worse still, John Hick has argued convincingly that Morris's view faces a dilemma: either the two minds each has its own set of causal and cognitive powers or they don't. ${ }^{3}$ If they do, then Morris doesn't have an answer to the objection that the relationship between the mind of God the Son and Jesus of Nazareth is precisely the same relation that the mind of God the Son bears to every other person. However, if each doesn't have distinct

\footnotetext{
${ }^{3}$ Hick (1989)
}

cognitive and causal powers, then Morris's theory apparently collapses into monothelitism, a heresy condemned at the Third Council of Constantinople (the Sixth Ecumenical Council) which was summoned in $680 \mathrm{CE}$. The monothelites believed that while there are two natures in the incarnation (hence they believed they could accept the teaching of Chalcedon) there was but a single will. When Morris claims that the cognitive and causal powers of God the Son are numerically the same as the powers of the earthly mind of Christ, he apparently means at least that the two minds share a will. Hick maintains that Morris must have been thinking that a 'mind' is not much more than a set of beliefs, and thus that Morris's view is overly intellectualistic. Now I agree with Hick in thinking that Morris must be assuming that minds are individuated strictly by sets of mental states (Humean bundles, it would seem). But what's wrong with the position is not that it is overly intellectualistic. For among the states in that bundle will presumably be conative states too; emotions will be part of the package. The problem is that such a method of individuation leaves out an essential characteristic of minds: their causal powers-cognitive, conative, and emotive powers. If each distinct mind requires its own set of powers (and that is very plausible), then the two-minds view will require two wills and Morris will lose his answer to the uniqueness question.

Before leaving our discussion of Morris, I'd like to make one further point. Although Morris's view is generally distinguished by its invoking of two minds, I can't see how any theorist who wants to obey the rules laid down by the creeds and councils can avoid positing a pair of minds in some fashion or other. For the claim that there was a single mind was held by Apollinaris and denounced as heresy by Pope Damasus in the Council of Rome $381 \mathrm{CE}$. As I understand it, Apollinaris held that incarnation consists of Son of God's taking the place of the human rational soul in the body of Jesus that contained only an animal human soul; Jesus was literally God made flesh rather than God made man. So if we are to be true to our desiderata, we will have to posit a view in which two distinct minds (or rational souls) come to inhabit or at least be uniquely associated with a particular human body. It is a terrific irony that Morris's two-minds account fails in that it does not posit two minds.

\section{THE COMPOSITIONAL ACCOUNT \\ OF THE INCARNATION}

One perspective that actually does posit two distinct minds is the compositional account of the incarnation. In the past few years, this Aquinas-inspired position has been championed by such philosophical luminaries as Eleonore 
Stump and Brian Leftow. ${ }^{4}$ According to the compositional account, Jesus Christ is metaphysically compositional. That is, Jesus Christ is quite literally composed of God the Son together with a body and rational soul (or human mind). Since God the Son is spirit and essentially a divine mind, and a human mind is also predicated of Jesus Christ, the view entails that there are two minds.

One clear motivation for this position is that it is seen as a way of dealing with the incoherence problem that Morris was attempting to solve. The properties that we take to be the limitation properties are properties not of the one incarnate person, but rather of the human parts of the person. Leftow says explicitly that we should read sentences like 'Christ died qua human but not qua divine' mereologically. That is, it is asserting that Christ had a part that died (the human mind and body-or at least the human body) and a part that didn't (God the Son). So for any of the problematic properties we can say at least that the one property is had by the divine part and the other is had by the human part. Stump and Leftow split company regarding what to say about what properties the one incarnate person had. Stump says that when a whole has a part that has a property, then the whole has that property 'to some degree'. But there is no contradiction in saying that a composite object has property $\mathrm{P}$ to some degree and lacks property $\mathrm{P}$ to some degree. So for example, someone who had very strong arms and very weak legs would be strong to a degree and not strong to a degree (and the same goes, of course for weakness). Leftow demurs here and claims only that some properties had by parts accrue to their wholes and some do not. We will have to decide, he says, on a case-by-case basis. So, for example, Leftow suggests that the omnipotence of God the Son transfers to the composite whole; similarly, the property of being created as instantiated by the human body and soul will likely transfer to the whole, while the property of being uncreated had by the divine part will not.

My outline of the compositional account can be briefer than my sketch of Morris's view because it is in a way, less complicated. Once one understands its mereological nature, one sees, at least roughly, how the compositional account will answer standard coherence objections.

That's not to say that the view doesn't have its share of difficulties. Notice that any of the objections to Morris's two-minds view to the effect that multiple minds entail multiple persons will apply to the compositional account. Although the emphasis isn't on the duality of minds here, the fact is that the account posits a distinctly human mind (or rational soul) and a

\footnotetext{
${ }^{4}$ Stump (2002) and Leftow (2002).
}

divine mind. As far as I can tell, neither Stump nor Leftow has a view about how these minds relate to each other. But since their position is that Jesus Christ is the mereological sum of God the Son, the human mind, and the body that the Son takes on, they at least have a theory that explains why you and I aren't also God incarnate: our human bodies and minds compose a human person that is ontologically distinct from either the person of God the Son or Jesus Christ. In short, Christ has one crucial part that we lack: God the Son. But as I pointed out at the end of the last section, it appears that no view that doesn't posit two distinct minds in God incarnate will satisfy the general 'creeds and councils' condition of adequacy on accounts of the incarnation. So the fact that the compositional account both entails two minds and also explains the uniqueness of the two-minded incarnation it posits should be seen as a theoretic strength rather than a weakness.

Be that as it may, the compositional account is problematic. In fact, I think it suffers from multiple debilitating problems. First, it fails to satisfy the identity desideratum. For if God the Son is a proper part of the composite object that is Jesus Christ, then God the Son is not identical with Jesus Christ since no part can be identical to the whole of which it is a proper part. So Jesus and the Son are numerically distinct entities. Worse still, the view, taken in light of the councils and creeds, entails that Jesus Christ is not a person. Here's why. Nestorianism was rejected at the First Council of Ephesus in $431 \mathrm{CE}$ for denying the hypostatic union and claiming that a distinct person was associated with each nature in the incarnation. The Council declared that although the incarnation involves complete human and divine natures, they are joined in a single person. But if there is a single person in the incarnation, and God the Son is not identical with Jesus Christ, then one of them isn't a person. But surely God the Son, the Second Person of the Trinity, is a person. Therefore, Jesus Christ is not.

The lesson here is that when the creeds speak of the Son's taking on human nature, they should not be understood to be making a mereological claim. The Son does not become a part of a non-personal whole. Rather, the Son bears a relation to human nature which allows him to be numerically one and the same as the human person Jesus Christ. Furthermore, it is very unclear to what extent the compositional account really helps with the incoherence objection. For the tradition insists that there be a single subject of predication in the incarnation. So even if we are to attribute the limitation properties to Christ's human part and the omni-properties to his divine part, we still have to have something to say about the single subject of predication that is the person of God incarnate. Saying that he has the divine properties in a respect and the human properties in a respect just doesn't answer the question of what properties to attribute to the single person. As Leftow says, we will have to 
decide the matter on a case-by-case basis; but if that is so, then it is unclear how the compositional account is offering anything like a substantive or systematic response to the incoherence objection.

Nevertheless, there is something suggestive about what the compositional account has to say about the charge of incoherence. For example, consider the following instance of the problem: one can be human only if one is created; one can be divine only if one is not created. Nothing can be created and not created, so therefore nothing can be divine and human. As we've seen, the compositional account will try to answer the objection mereologically: Jesus Christ has a human part that is created and a divine part that is uncreated. Some properties of proper parts accrue to the whole and some do not. In this case on the compositional account, one can plausibly argue that since the composite Christ consists of two significant created parts, the whole takes on the property of being created rather than uncreated (even while it contains the uncreated part of God the Son). ${ }^{5}$

\section{ADOPTING INSIGHTS FROM THE COMPOSITIONAL ACCOUNT}

While I believe we've seen ample reason to reject the compositional account, and hence the adequacy of any defensive manoeuvre that depends upon it, there is something one can say that is in the near neighbourhood and that is promising. One can maintain that in taking on human nature, God the Son came to bear a relation to the acquired human mind and body that allowed some of the properties of that mind and body to become properties of his without claiming that the mind and body were parts of his.

To see this, consider the following example. Robert is an actor who will begin a role in six months in which he will play the part of a man who weighs eight hundred pounds. To get into the character properly, Robert is fitted with a costume that will give him the realistic appearance and the manoeuvrability of a man who, at six feet tall, weighs eight hundred pounds. Furthermore, when Robert is in costume he in fact weighs eight hundred pounds-or, more exactly, the combined weight of Robert and his costume is eight hundred pounds. Let's further suppose that he will not remove the suit until he has finished playing this part in nine months' time. Consider, then, the following claims about Robert when he is many months into his character:

\footnotetext{
${ }^{5}$ I subject the compositional account to a more rigorous attack in Senor (2007).
}

1. Robert weighs eight hundred pounds.

2. Robert can move only laboriously.

3. Robert gets winded just walking down the hall to go to the bathroom.

4. Robert feels ashamed when he goes out in public.

Let's stipulate that before putting on his present costume, none of these claims is true. Robert is a man who, at one hundred-eighty pounds is in good shape, is light on his feet, and takes deserved pride in his appearance. But now that he's been in character for quite a while, it would be wrong or at very least misleading to continue to flatly deny the truth of (1)-(4). The sober metaphysical truth is that the costume is not part of him; instead he is embedded in it in such a way that it is through his character (and the costume) that he experiences the world and even, to a degree, himself. So while he doesn't literally weigh eight hundred pounds, that is what the scale will read anytime he steps on it, and he feels the way an eight-hundred-pound man feels-_both with respect to his wind as he walks, the speed at which he is able to move, and even the way he knows he is perceived by other people. Getting back to our list, then, while (1) is strictly speaking false, (2)-(4) are true. And Robert has the attributed properties in virtue of them being embedded in a costume that is not literally part of him.

I believe it will be useful to make a distinction between a couple of different ways of having properties. Some properties a thing has strictly in virtue of its parts-both proper and improper. Robert has the properties of being human, of being intelligent, and of being male in virtue of the parts that compose him. However, while in costume Robert also has the properties of being slowmoving and not fitting into a standard chair. These are properties he has not in virtue of his parts but in virtue of the suit into which he is embedded. Even so, it seems to me, they are genuinely properties he currently possesses since it is straightforwardly true that he can't now fit into a chair or walk quickly. Let's call properties that stem directly from one's parts 'direct properties'. In contrast, properties that one has only because one is embedded in a particular circumstance will be termed 'derivative properties'. So my being able to type, walk, and read are direct properties of mine; my ability to be in St Louis tomorrow or fix my toilet are derivative since I have those properties only in virtue of being embedded in a circumstance in which there is (relatively) high-speed travel and toilet-fixing tools.

Let's complicate matters a bit. Suppose that what is essential to Robert is that he have the DNA he has. Suppose further (and unrealistically) that anyone with that DNA will always be thin and, barring injury and while in youth, swift (henceforth, I'll assume the qualifier 'barring injury and while in youth' without stating it). Put in the terminology I have here 
explicated, it is essential to Robert that he have the intrinsic properties of being thin and swift. But now here's an incoherence objection to Robert's current predicament: Nothing can be Robert that doesn't have Robert's DNA. Nothing can have Robert's DNA and not be thin and swift. However, no one who wears the fat suit can be either thin or swift. But it is impossible for anyone to be both 'thin and swift' and 'neither thin nor swift'. So therefore it is impossible for Robert to wear the fat suit

Something has gone wrong, since it is surely possible for Robert to be embedded in the fat suit and when he is to be neither swift nor able to fit into a chair. The problem occurs early on in our assumption that anything with Robert's DNA would be swift and able to fit into a standard chair. What the DNA can be expected to do is to guarantee that in his youth and apart from injury, Robert will have the direct property of being swift and thin provided that he is embedded in a circumstance that renders that possible. Now I'd very much like to have something enlightening to say about what being embedded in a circumstance comes to, but I'm afraid that I do not. What is crucial for our purposes, though, is that being embedded doesn't change one intrinsically even if it does alter one's properties. Being in the suit makes Robert now unable to fit into a chair or move swiftly. Yet (and this is the big point) he hasn't changed in any intrinsic way. (Notice that if his acting role required him to gain six hundred and twenty pounds instead of wearing a suit of that weight he would have changed substantially in a way that he hasn't changed by putting on the suit.) So while we have to give up the claim that given his DNA, Robert is necessarily swift and thin, we can continue to hold that his DNA is essential to him and that his parts necessitate that he be intrinsically swift and thin even if his circumstances prevent him from being this, all things considered.

Let's consider again (1), i.e., the claim that Robert weighs eight hundred pounds. Because the suit isn't a part of Robert and one's weight is purely a function of the collective weight of one's proper parts, (1) is false. Even so, Robert has a pretty good idea of what it is like to be an eight-hundred pound man. That is, although Robert isn't even derivatively eight hundred pounds, his experience of the world, while in costume, is very much like that of a person who weighs that much. Let's call properties like this-that is, properties that a person doesn't literally have but which the person's experience is as though he had-ersatz properties.

Assuming a story like Robert's makes sense, we can make an analogous claim about the incarnation. Some properties had by the human mind and body of Christ are had by the Son and some aren't. So being created will not be even an ersatz property of the Son since it is a property of the human mind and body that is not come to be had by the Son, and isn't really even part of the way the incarnate Son experiences the world (he experiences human limitations but there is nothing particularly experiential about the property of being created). However, arguably, being spatial will be a property that the Son will now have derivatively - that is, in virtue of the relationship he bears to the spatial human body (and perhaps mind). Being limited in knowledge and power might also be plausibly thought to be derivative attributes of the incarnate God. Even though he would not have them were he not tethered to the human body and mind, given that his experience of the world during the incarnation was severely mediated by that body and mind, we can plausibly claim that he was so limited during his earthly ministry.

I'm getting ahead of myself. For as we will see, I think that a broadly kenotic perspective can make the most sense of these kinds of insights and it is to that position that we will turn after taking stock.

\section{ADOPTING INSIGHTS FROM THE TWO-MINDS VIEW AND MOTIVATING KENOTICISM}

Over against both the two-minds view and the compositional account, the kenotic view attempts to do its explicatory work in a somewhat different fashion. The emphasis in the first two approaches is additive; the focus is on God the Son's assuming or taking on humanity. Taken neat, this seems to cause problems with coherence. And even assuming the omnipotent, omniscient, omnipresent Son can add a human nature to his being, in what sense is the resultant person a genuine human being? The claim that the Son took on human nature needs to be paired with the view that in doing so the Son surrendered or gave up or at least qualified divine characteristics he previously had. ${ }^{6}$ Whether in the end this helps or not (and I think it does), I believe that it is a significant motivation for contemporary kenotic theories to which we will turn presently. ${ }^{7}$ For the moment, though, let's take stock of what I've argued (or at least claimed) so far.

I've argued above that although Morris's two-minds theory is flawed, his point that humanity should be seen as a natural kind and hence that the concept of 'humanity' is a natural kind concept is very important for making

${ }^{6}$ Although I'm using expressly temporal language, I don't mean to beg any questions here about divine atemporality. Perhaps the timelessness advocate can translate these claims into terms of logical or modal order.

I'm not suggesting that kenoticism has historically been motivated primarily by the metaphysical issues which are the focus of this paper but only that one sees its use bete as a motivation to take the view seriously. 
headway on a coherent account of the incarnation. For as long as the concept is thought of as a cluster concept or nominal essence, then it will consist of the set of qualities that we standardly employ when we think about humans and pick them out amongst other things. We will then naturally think that being limited in knowledge and power, created, mortal, and perhaps even morally flawed are all essential to our humanity. However, if humans are natural kinds, then the essence of what it is to be human is to be found not in armchair conceptual analysis but in biology: to be human is to have the human genome. But it doesn't fall out of the natural kind concept of humanity that nothing could be human and yet unlimited in power.

As Morris himself recognizes, it won't do to simply make what we might think of as the anti-kenotic move and insist that, for any inconsistent pair of properties that one is tempted to attribute to Jesus Christ one should attribute the divine property at the cost of the human property. For even if that were a way of resolving the incoherence objection, it would give us an account that would fail to satisfy our desiderata since it would effectively gut the humanity claim of all content. We saw when we discussed the compositional account that even though it is a mistake to think that the human body, human mind, and God the Son literally compose Jesus Christ, there is a way of plausibly arguing that the properties had by the Son in virtue of taking on humanity accrue to the Son at least as ersatz properties and perhaps even as derivative properties. So while we might say that some of the alleged inconsistent properties are in no good respect both attributed to the incarnate Son because the limitation property turns out not to be essential for being human, we can say that each member of some other pairs are had by the incarnate Son (even if one of the properties is only derivative, or even ersatz).

So while I think that both Morris's two-minds view and the compositional account have fundamental flaws that keep either from being generally adequate theories of the incarnation, there are important insights offered by each and which should be incorporated into a metaphysical account of the incarnation. In what follows, I will sketch a role that the kenotic view can play which, in addition to the aforementioned insights, seems to me to provide a theory that manages to both provide a solid answer to the incoherence charge and satisfy our desiderata.

\section{THE KENOTIC PERSPECTIVE}

Kenoticism is something of a newcomer in christological theory. Originating in Germany in the nineteenth century in the work of Gottfried Thomasius and W. F. Gess, the emphasis at the time was not so much on squaring the doctrine of the incarnation with Leibniz's Law and concerns about incoherence. Rather, the goal was to incorporate the then-current research into the 'historical Jesus' into the life of faith, not in a way that would reduce the bold metaphysical claims of Chalcedon but instead as a means of using what was being newly learned about the life and times of Christ as a way to better understand his humanity. For God incarnate must be experientially rather than just metaphysically human if he is to truly join us in our condition. ${ }^{8}$

The fundamental biblical impetus for the kenotic perspective comes from an early hymn that Paul quotes in the second chapter in his letter to the Philippians. The relevant verses are these:

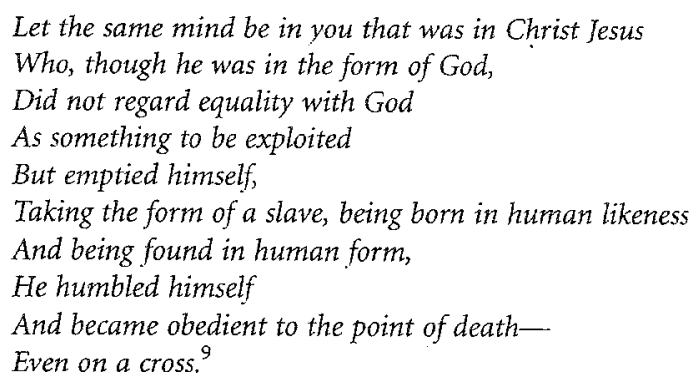

The key to figuring out how to mine this passage of its christological import is in understanding what is meant by 'emptying'. It should be noted at the outset that the kenotic perspective can't be the entire solution to the incoherence objection that we've been discussing. For if we were to claim that in every instance of potential conflict, the divine property has been abandoned to allow for the taking on of a human nature, then the Son's divinity would be gutted and we would have abandoned one of our desiderata. So if kenoticism is to be helpful here it will have to be as a supporting role or perhaps as part of an ensemble. But as we've seen above, there are insights that a kenoticist can glean from the other views. In what follows, we will look at a major difficulty facing any account that is even partially kenotic and at how contemporary theorists have attempted to deal with it. In the end, I'll reject the favoured solution to the problem and offer in its place one of my own.

The kenotic perspective faces an obvious, potentially devastating objection before it even leaves the proverbial gate. Recall the second desideratum listed in this paper's first section, i.e., that any candidate account of the incarnation

\footnotetext{
${ }^{8}$ See Thompson (2006).

9 Philippians 2: 5-8, New Revised Standard Version.
} 
entail that God the Son had whatever properties are essential for divinity even during his earthly ministry. Inasmuch as the kenotic perspective attempts to deal with at least some varieties of the incoherence objection by claiming that God the Son lays aside some divine attributes in order to become human, it runs the risk of denying the divinity of Christ. For the doctrine of the incarnation is not simply the doctrine that God became human; were that all it asserted then perhaps we could be content with the idea that taking on humanity meant laying aside divinity. However, the doctrine requires that God incarnate be fully human and fully divine. So how is the kenotic perspective to even get started if what is fundamental to it is the Son's selfemptying of divine properties? Let's call this the 'Not Fully God' objection to kenoticism.

Let's look at a specific example, in particular the attribute of omniscience. The Christian philosophical tradition insists that omniscience is required for divinity. Put slightly differently, it is part of the job description, one might say, for being God that one be omniscient. On the other hand, being human plausibly entails finitude and that would seem to require being limited in knowledge. The kenotic perspective will advocate that we maintain that the Son empties himself of omniscience in order to take human form. The question, then, is why this doesn't entail that the Son surrenders his divinity. The answer that seems to have the most support among contemporary contributors to the analytic philosophical theological literature is essentially this: ${ }^{10}$

The incarnation teaches us some things about the nature of God. Whereas, in our recognition of God's limitlessness and infinite nature, we might have originally assumed that being omniscient was a requirement of divinity, we can infer from the fact that Jesus himself acknowledged that there are things he didn't know, together with the tradition's claim that Christ was divine, to the conclusion that omniscience is not necessary for divinity. However, this doesn't mean rejecting the idea that God is the Anselmian perfect being. If omniscience were essential for divinity, and if no omniscient person could be human (or could have a first-person understanding of what it is like to be human), then God could not become human while continuing to be God (or at least couldn't become a human who could empathize with other humans). Would a being who is incapable of such an incarnation be greater than a being who was able to be fully incarnated? It's hard to see that perfect being theology will require us to answer yes. Perfect being theology is guided by the conviction that we should attribute the greatest set of compossible great-making properties to God. Exactly which set is the greatest will be a matter of controversy even among those who hold to perfect being theology. Furthermore, even if the above reasoning shows that

\footnotetext{
${ }^{10}$ Morris was the first to suggest this possibility, although he rejects it in the end. Ronald
} Feenstra embraces it, as do Stephen Davis (2006a) and C. Stephen Evans (2006a). omniscience simpliciter isn't an essential property of divinity, there is a reasonable facsimile at the ready. The kenoticist will agree that omniscience is generally a greatmaking quality which a perfect being would give up only if there was an overriding reason to do so. Armed with this insight, the kenoticist can claim that while omniscience simpliciter isn't an essential attribute of divinity, the related quality 'omniscient-unless-freely-and-temporarily-choosing-to-be-otherwise' is. ${ }^{11}$ Our focus here has been on omniscience but there are other attributes for which a similar distinction can be drawn: omnipotence and omnipresence come to mind as possibilities.

No doubt it is obvious that this strategy can work for only certain ostensible properties of divinity: necessary existence and being creator of all that is other than God's self do not admit of kenotic renderings. But as we've seen, there are other, not implausible ways of dealing with these problems (it would seem to be consistent with taking on a human body and mind that one have these properties that Stephen Davis labels 'ungiveupable').

The question I want to address now, then, is not the extent to which kenotic understandings of the attributes can be generated, but their desirability. For the account of the divine essence that we will end up with if we give kenotic renderings of several of the traditional attributes will have an air of artificiality about it. Instead of the divine essence being composed (in part) of such unrestricted attributes as omnipotence, omniscience, and omnipresence, the kenotic perspective currently under consideration has it that each of these attributes is not, in fact, required for divinity, that divinity requires only the related property of having that attribute unless it has been freely given up. But there are two ways that such an account is problematic: first, it appears to be ad hoc, and second, the properties that are being claimed as kind essential for divinity are not sufficiently fundamental or basic. Let's look at these in turn.

The traditional Christian holds that Jesus Christ was fully God and fully human. Accounts of the incarnation that are purely additive are thus in principle acceptable because rather than removing anything from his divinity, God the Son simply adds on a complete human nature. However, the defender of the kenotic perspective as outlined above emphasizes the surrender of certain divine properties. The only way that she can do this and yet continue to claim that the Son was divine during his earthly ministry is to alter the standard account of the divine nature. As we've seen, she alters the account by adding a caveat clause that is specific to the problem she is thereby trying to solve. But this comes perilously close to being a paradigm of an ad hoc emendation. True, the advocate of the kenotic perspective who favours this response to the 'Not Fully God' objection will say that the incarnation has 
taught us something about the nature of God. But that rejoinder, while effective against the complaint that altering the divine attributes is religiously objectionable, doesn't address the ad hoc nature of the changes. Learning something about divinity from the incarnation is fully appropriate, but one might have hoped that what we learn would be more general or maybe even deeper than the simple addition of a caveat clause on the traditional attribute. As we will see, I do think we can learn something about the divinity via the incarnation that takes us a good deal further.

This leads to my second objection: altering the divine properties in the way under consideration illustrates that the properties that are being claimed as constituting the divine essence are not suitably fundamental or basic to play that role. Consider the following case. Smith believes that an essential characteristic of tigerhood is 'being black-striped'. As long as every tiger Smith has seen had black stripes (and let's suppose that Smith has seen a lot of tigers), it might well be plausible for Smith that being black-striped is essential for being a tiger; that is, nothing could be a tiger that was not black-striped. But if his travels take him to India and he is confronted with a particular variety of white tiger, he'll have to change his perspective. (I take it that Smith's claiming they aren't tigers because they aren't black-striped would not be reasonable.) Suppose as a result of his encounter with the white tiger Smith alters his view of the nature of tigers. Instead of taking them to be essentially black-striped, he now believes 'being black-striped unless white' is essential for tigerhood. Surely, there is something too easy about making this particular change. Notice, though, his new belief might be true and rational. For if his experience with tigers is vast and if the only non-black-striped tigers are a certain type of white tiger, then it is not only true that every tiger is either black-striped or white, but it might well be true that nothing could be a tiger that fails to have this disjunctive property.

If the belief that 'being black-striped unless white' is essential for tigerhood stands a good chance of being true and is not irrational, then what is wrong with it as a response to seeing white tigers? I submit that the problem is that being confronted with the counterexample to the original belief should make Smith think that maybe being striped or non-striped doesn't bear a particularly significant relation to what it is in virtue of which a tiger is a tiger. Notice that for any kind, there are terrifically unenlightening properties that are essential to it. For instance, being coloured and opaque are both essential to tigerhood (nothing non-coloured and transparent could be a tiger), although I think no one would want to say that they tell us anything interesting about the essence of being a tiger. To be a tiger is to have the natural kind essence that tigers have. To use the current biological lingo, it is to have the tiger genome.
As far as I can tell, one who adopts a kenotic reading of the divine attributes is guilty of doing essentially what Smith does above. For if we are to learn something about the nature of divinity from the incarnation, and essentially what we learn is that the Son is able to divest himself of some of the standard divine attributes, then we should conclude that those attributes do not compose the deep essence of divinity, and we should suspect that perhaps the attributes in question were not of the right sort in the first place. As with Smith's tigerhood belief, the problem with the particular kenotic response to the 'Not Fully God' objection we are considering is not that it isn't true that nothing could be God that wasn't omniscient-unless-freely-and-temporarilychoosing-to-be-otherwise and it might well be reasonable for one to think this. The problem is that one now lacks a reason for thinking that this particular property is a suitably deep or fundamental property capable of serving as (a part of) the essence of divinity.

\section{AN ALTERNATIVE KENOTIC PERSPECTIVE}

I will now sketch a position that will take insights from all three perspectives we've been considering. I begin by briefly developing an alternative kenotic answer to the 'Not Fully God' objection and will finish by outlining an account according to which God the Son was embedded in the human mind and body during the incarnation, working through the mind and body of Jesus of Nazareth. ${ }^{12}$

I begin with a simple but important point. The 'Not Fully God' objection gets its purchase not because the kenotic perspective claims that divine properties are surrendered, but because it seems to entail that properties essential to divinity are given up. If there is a good way to argue that what is given up are divine properties that are not essential to divinity, then the kenoticist might have a philosophically and religiously adequate response. I will now attempt to forge such a way.

As we've seen, Thomas Morris's distinction between cluster concepts and natural kind concepts plays an important role in seeing how to begin to argue for the coherence of the doctrine of the incarnation. We should think of humanity along the lines of tigerhood rather than bachelordom. What it is to have the essence of humanity is to have the human genome. However, when it comes to how to think about divinity, Morris and others continue to think in

\footnotetext{
12 Some of the ideas in the next several paragraphs were first discussed in Senor (1991).
} 
terms of a cluster concept. To be divine is to be omnipotent, omniscient, omnibenevolent, necessarily existent, and all the rest; the essence of divinity is nothing over and above the collection of those properties. However, it seems to me that thinking of divinity as a cluster concept is no better than thinking of humanity as a cluster concept. Let's reflect for just a bit on the relationship between natural kinds, essential properties, and other attributes.

Let's take water for example: what is essential to water is that it be composed of two parts hydrogen and one part oxygen. These are its essential characteristics. In addition, water has what I'll call standard attributes. These are properties that an object commonly or typically has but which are not properties in virtue of which the thing is an exemplar of its kind. Among standard attributes, some are ceteris paribus and some are secondary-essential. A ceteris paribus property is a property that an object will typically have (or maybe will have in its natural or paradigmatic state), but which is not essential to the object's being a member of its kind. So, for example, water has the ceteris paribus property of boiling at 100 degrees Centigrade and being tasteless. But if you add salt to the water, both of those properties will no longer be exemplified yet you'll still have water. On the other hand, a secondary-essential property is a property that is essential for kind membership, but which is derivative in a way the fundamental essential properties are not. So consider again tigers and suppose that given the tiger genome, the only way a tiger can fail to have black stripes naturally is if it is white. Then Smith's belief that 'being black-striped unless white is kind essential for tigerhood' is true, but only because it is a secondary-essential property: it necessarily supervenes on those properties that are fundamentally essential.

Given this conceptual machinery, I propose the following: we should think of divinity as a supernatural kind. To be divine is to have whatever it is that is at the essence of the being who created the world and became incarnate in Jesus Christ. It is to have the God 'genome'. The standard divine attributes are not, then, fundamental essential properties but are standard properties of divinity: they are properties that a being with that essence will paradigmatically instantiate. Some of these properties will be secondary-essential but some will be ceteris paribus. Being the absolute ground of all being, source of all power, and necessarily existent are prime candidates for secondaryessential properties: any being who is of the divine substance will necessarily exemplify them.

On the other hand, a good case can be made for saying that omniscience is only a ceteris paribus property. On reflection, omniscience was never well suited to be a fundamental essential property. For being omniscient reduces to having and exercising maximal cognitive power (the ability to have direct knowledge of all propositions and entities). One might suppose that having maximal cognitive power would be secondary-essential but why should we think that its exercise would be as well? Of course, one might say that typically or paradigmatically, the power is utilized, but if one thinks a certain kind of freedom is important for a divine being, one might well think that there are possible circumstances in which that power is not fully used.

Omnipotence is a tougher case because to be omnipotent requires only having power and not, as with omniscience, fully exercising it. To give up omnipotence, then, it isn't enough that one quit exercising the full range of one's powers (for those powers are never fully realized in any event), but one must give up the ability to exercise them. In short, the powers of omnipotence must be unavailable if omnipotence is to genuinely be given up. I don't have anything definitive to say here but I do want to note that there is an interesting middle ground between having the powers of omnipotence readily available to one even if one isn't fully using them, and not having them and being unable to get them back at the time should one change one's mind. Suppose Katie gives up chocolate for Lent. She does this successfully (if minimally) as long as she does not eat chocolate in the forty days before Easter. If Katie's will is just barely strong enough to pull it off, there will be lots of counterfactual instances in which her will is weak and she gives in. Her managing to hold out until Easter is, to a certain degree, a matter of luck. This then is a clear case in which Katie doesn't in fact eat chocolate but (as we might say) could have and even would have in the right circumstances.

Suppose Katie wants so badly to keep to her Lenten vow that she sees a hypnotist who induces in her a deep repulsion to chocolate to the point that she is unable to eat or touch it. Even if she were to want to eat or touch it (perhaps she's offered a thousand dollars if she would and she really wants the thousand dollars), Katie just wouldn't be able to bring herself to do so. In these circumstances, Katie doesn't eat chocolate; but more than that, given the efficacy of her hypnosis, she can't eat it either.

Finally, suppose Katie is a person of remarkable will power and commitment to her word. If she vows to do something, she always follows through on it. Unlike Katie in the first case, there is no luck involved in her not eating chocolate; in the first case, although Katie didn't eat chocolate, she could have and would have. Unlike Katie in the second case, in the third case nothing other than her will prevents her from eating chocolate; in the second case she didn't eat chocolate and she couldn't have eaten it. In the third case, however, Katie didn't eat chocolate and could have eaten it, but she wouldn't eat it. That is, at nearby worlds where Katie gives up chocolate for Lent, she doesn't eat chocolate (even though she could). Furthermore, since she knows that once her will is set there is no going back, Katie thinks like someone who can't eat chocolate. She doesn't see eating it as an option. This makes her very different 
from case-one Katie who is willing to bail out if the going gets too hard, and who knows that she really can (and even might) give in. Psychologically, casethree Katie is more like case-two Katie. In fact, we can make them even more psychologically similar if we say that, in case three, Katie comes to believe that she can't eat chocolate. Maybe the hypnotist of case two produces in Katie a false belief that she is physically unable to consume the dark treats. Now Katie will not only think that the strength of her will power will see her through, but she'll believe that she is unable to go against her vow (even though she actually is able to).

The application of the Katie example to the case of omnipotence and the incarnation is straightforward. Suppose that due to metaphysical scruples (i.e, a conviction that an omnipotent being could not cease to be omnipotent even temporarily), the friend of the kenotic perspective can't see omnipotence as a ceteris paribus property and hence giveupable in the incarnation. She can nevertheless maintain that something an awful lot like giving it up can happen. In taking on a human nature, God the Son lays aside the powers of omnipotence not simply in the sense that (like case-one Katie) he doesn't, in fact, make use of them in his earthly ministry but in the much stronger sense that he would not use them during that time (like case-three Katie). Thus, there is a strong counterfactual component to the setting aside of the divine powers even if he doesn't technically cease to be omnipotent during that time. Furthermore, if we include in the incarnational scenario that the Son has laid aside omniscience and is operating with a human mind, then there is no reason to assume that he believes he's omnipotent even if he still is. So he not only would not make use of those powers but he doesn't believe that even could be an option.

For those of us who are less metaphysically scrupulous, however, there is no good reason to insist that the Son remained omnipotent when incarnated. For if he didn't, then omnipotence is but a certeris paribus property of the divinity and that doesn't imply that Christ was not fully God.

\section{PUTTING THE PIECES TOGETHER}

I conclude with a bare-bones sketch of an account of the incarnation that borrows features from all three views we've been discussing. It has more in common with Morris's general christology than it does with the compositional account, but it is also pretty clearly a variety of kenoticism as outlined in the previous section. A more complete kenotic theory would have something to say about the sense in which immutability can be maintained even while divine attributes are given up and the effect of kenosis on the metaphysics of the Trinity. Those topics will have to wait for another time.

1. Humanity is a natural kind; divinity is a supernatural kind. One doesn't learn the essence of either by armchair reflection. This position is both independently motivated and provides the philosophical theologian with some conceptual slack. Yet it comes with attendant worries. For example, one learns about the nature of human beings via the natural sciences (at least). But how does one learn anything about the divine essence construed as (somehow) akin to a genome? We can't very well do science on God. There's no time to get into these matters sufficiently but let me make two quick points. Yes, it seems to me that if the supernatural kinds thesis is right, then we are likely to never know the essence of divinity; it will be a mystery. But that is fine with me and accords well with my fifth desideratum. Second, though, there is still a place for philosophical theology as long as we think that something about at least God's secondary-essential properties can be gleaned from the scriptures, the creeds, etc. What my position does suggest is that whatever we learn about the nature of God will be crucially dependent on revelation.

2. God the Son assumed a human body and mind. Rather than seeing the incarnation as primarily the taking on of a set of human qualities, we should think in the concrete terms that the compositional account asks us to think in. In order to be true to the councils and creeds we must ascribe to God incarnate a human mind in addition to the divine mind of God the Son. What made Morris's two-minds view problematic was (i) the thought that two centres of consciousness was inconsistent with there being a single person in the incarnation; and, more importantly, (ii) Morris turned out to have no answer to the uniqueness problem-what made the relationship between the divine mind of God the Son and the human mind he assumed unique? I'm going to wait just a bit before addressing the first problem but I want to tackle the more significant problem now. Morris tried to answer this by claiming that they shared a set of causal and cognitive powers, but that was rejected for its monothelitism. But there is a better answer that can be gleaned from the compositionalist camp. Both Leftow and Stump consider the following objection to their position: standardly, a human mind and body composite compose a human person. But if the human mind and body assumed by the Son also compose a human person, then there are two persons in the incarnation (the human and God the Son), and that is to court Nestorianism. Leftow's and Stump's replies are complex and subtle but the bottom line is this: they claim that because the human mind and body never exist independently of the Son, but are assumed by him at the moment each begins to exist, 
the normal process of the composition of a human person is blocked. Counterfactually, they would have composed a human person had they not been joined to the Son, but as things stand they do not. So the relationship between the human mind assumed by God the Son and every other human mind are distinct: other human minds belong to distinct persons but the human mind and body of God the Son fail to compose a person; rather, they are assumed by God the Son.

3. God the Son was embedded in the human mind and body in the sense that it was only through them that the Son acted while on earth. The view I favour identifies God the Son with Jesus Christ (thus satisfying the first desideratum); both terms refer to a single person. Thus my view is not a version of the compositional account of the incarnation, since I'm not claiming that Jesus Christ has God the Son as a proper part. Furthermore, in taking on the human mind and body, the Son has a single centre of consciousness and locus of action: the human mind and body. The Son is not conscious of or through the divine mind during his earthly ministry. What he consciously knows of the world he gets from two sources-typical human cognition and revelation.

4. There is no single way of dealing with the incoherence objection. For some inconsistent pairs of properties, the right thing to say is that God incarnate had the divine but not standard human properties (being uncreated and necessarily existent, say); for others we should say that he had the human but not standard divine properties (omniscience, omnipresence, and maybe omnipotence). In all of these cases, though, we'll be able to say why it is tempting to ascribe the inconsistent properties (because typical or paradigm cases of beings of the kind in question have the relevant properties--i.e., the properties are ceteris paribus properties of that kind). For the incarnate God will continue to be intrinsically just as he was prior to the incarnation; the changes involved in his human embedding do not alter anything intrinsic to him.

\section{CONCLUSION}

Admittedly, the position I'm advocating is something of a hodge-podge. But it might be that the best we can do in constructing models of the metaphysics of the incarnation is to shoot for accounts that meet our desiderata, are apparently logically consistent (or at least are not apparently logically inconsistent!), and explain the relevant data as well as or better than their competitors.
I have argued here that each of the three main contemporary models is problematic even while being insightful. I've attempted to pull together the insights of the competing views of others while leaving aside their woes. In the end, what I have is loosely a kenotic view that distinguishes between the giving up of divine properties and the giving up of essential divine properties, allowing for the former but not the latter, and which has resources for responding to the incoherence objection while incorporating mystery at its core. ${ }^{13}$

${ }^{13}$ This paper has benefitted from the comments of the participants at the 2009 Logos Conference held in May at Notre Dame and at the incarnation conference held at the University of Oxford in September of 2009. In particular, I've been helped by conversations with and comments by Oliver Crisp, Brian Leftow, Tom Flint, Dan Howard-Snyder, and Mike Rea. Thanks also to Mike Rea and Anna Marmodoro for inviting me to participate in the aforementioned events. 